\title{
Tuberculosis incidence among migrants according to migrant status: a cohort study, Denmark, 1993 to 2015
}

Kristina Langholz Kristensen ${ }^{1,2}$, Troels Lillebaek ${ }^{1,3}$, Joergen Holm Petersen ${ }^{4}$, Sally Hargreaves ${ }^{5}$, Laura B Nellums ${ }^{6}$, Jon S Friedland 5 , Peter Henrik Andersen ${ }^{7}$, Pernille Ravn ${ }^{8}$, Marie Norredam ${ }^{9,10}$

1. International Reference Laboratory of Mycobacteriology, Statens Serum Institut, Copenhagen, Denmark

2. Department of Pulmonary and Infectious Diseases, Nordsjællands Hospital, Hillerød, Denmark

3. Global Health Section, Department of Public Health, University of Copenhagen, Copenhagen, Denmark

4. Section of Biostatistics, University of Copenhagen, Copenhagen, Denmark

5. Institute for Infection \& Immunity, St. George's, University of London, London, United Kingdom

6. Division of Epidemiology and Public Health, School of Medicine, University of Nottingham, Nottingham, United Kingdom

7. Department of Infectious Disease Epidemiology and Prevention, Statens Serum Institut, Copenhagen, Denmark

8. Department of Medicine, Infectious Disease Section, Herlev-Gentofte Hospital, Copenhagen, Denmark

9. Research Centre for Migration, Ethnicity and Health, University of Copenhagen, Copenhagen, Denmark

10. Department of Infectious Diseases, Section of Immigrants Medicine, University Hospital Hvidovre, Hvidovre, Denmark

Correspondence: Kristina Langholz Kristensen (krlk@ssi.dk)

Citation style for this article:

Langholz Kristensen Kristina, Lillebaek Troels, Holm Petersen Joergen, Hargreaves Sally, Nellums Laura B, Friedland Jon S, Andersen Peter Henrik, Ravn Pernille, Norredam Marie. Tuberculosis incidence among migrants according to migrant status: a cohort study, Denmark, 1993 to 2015 . Euro Surveill.

2019;24(44): pii=1900238. https://doi.org/10.2807/1560-7917.ES.2019.24.44.1900238

Background: Migrants account for the majority of tuberculosis (TB) cases in low-incidence countries in western Europe. TB incidence among migrants might be influenced by patterns of migration, but this is not well understood. Aim: To investigate differences in TB risk across migrant groups according to migrant status and region of origin. Methods: This prospective cohort study included migrants $\geq 18$ years of age who obtained residency in Denmark between 1 January 1993 and 31 December 2015, matched 1:6 to Danish-born individuals. Migrants were grouped according to legal status of residency and region of origin. Incidence rates (IR) and incidence rate ratios (IRR) were estimated by Poisson regression. Results: The cohort included 142,314 migrants. Migrants had significantly higher TB incidence (IR: 120/100,000 person-years (PY); 95\% confidence interval (Cl): 115-126) than Danish-born individuals (IR: 4/100,000 PY; 95\% Cl: 3-4). The IRR was significantly higher in all migrant groups compared with Danish-born $(p<0.01)$. A particularly higher risk was seen among family-reunified to refugees (IRR: 61.8; 95\% Cl: 52.7-72.4), quota refugees (IRR: 46.0; $95 \% \mathrm{Cl}: 36.6-57.6)$ and former asylum seekers (IRR: 45.3 ; $95 \% \mathrm{Cl}$ : 40.2-51.1), whereas lower risk was seen among family-reunified to Danish/Nordic citizens (IRR 15.8; $95 \% \mathrm{Cl}: 13.6-18.4$ ) and family-reunified to immigrants (IRR: 16.9; $95 \% \mathrm{Cl}: 13.5-21.3$ ). Discussion: All migrants had higher TB risk compared with the Danish-born population. While screening programmes focus mostly on asylum seekers, other migrant groups with high risk of TB are missed. Awareness of TB risk in all high-risk groups should be strengthened and screening programmes should be optimised.

\section{Introduction}

Improving tuberculosis (TB) care among migrants is considered a key public health priority towards global elimination of TB [1]. Migrants account for the majority of TB in low-incidence countries, defined as those with a notification rate $<10$ per 100,000 population per year [1] and comprise over $70 \%$ of TB cases in countries like Denmark (incidence: 5/100,000 population/year) and the United Kingdom (UK) (incidence: 9/100,000 population/year) $[2,3]$. While TB rates in native-born European populations are decreasing, the proportion of cases occurring in migrants is increasing, which may be partly attributed to the recent surge of refugees in some European countries [4]. In this paper, migrants refer to all groups of foreign-born individuals.

Migrants from high-incidence TB countries, defined as notification rate $>20 / 100,000$ population/year [5], are likely to be at increased risk of TB several years following migration because of an increased risk of reactivation of latent TB (LTBI) [6-9]. Some migrants may also be vulnerable to TB because of risk factors associated with migration [10]. Refugees in particular are potentially exposed to poor and dangerous travel conditions, overcrowded housing and poor access to healthcare during flight [11]. After arrival in the host country, potential barriers such as language, lack of knowledge regarding the healthcare system and patient rights, and lack of entitlement can present challenges to accessing the healthcare system [12].

Across Europe, different strategies for TB screening among migrants have been implemented to improve TB detection and treatment, and to reduce the burden of 
TABLE 1

Migration status terminology used in cohort study of tuberculosis, Denmark, 1993-2015

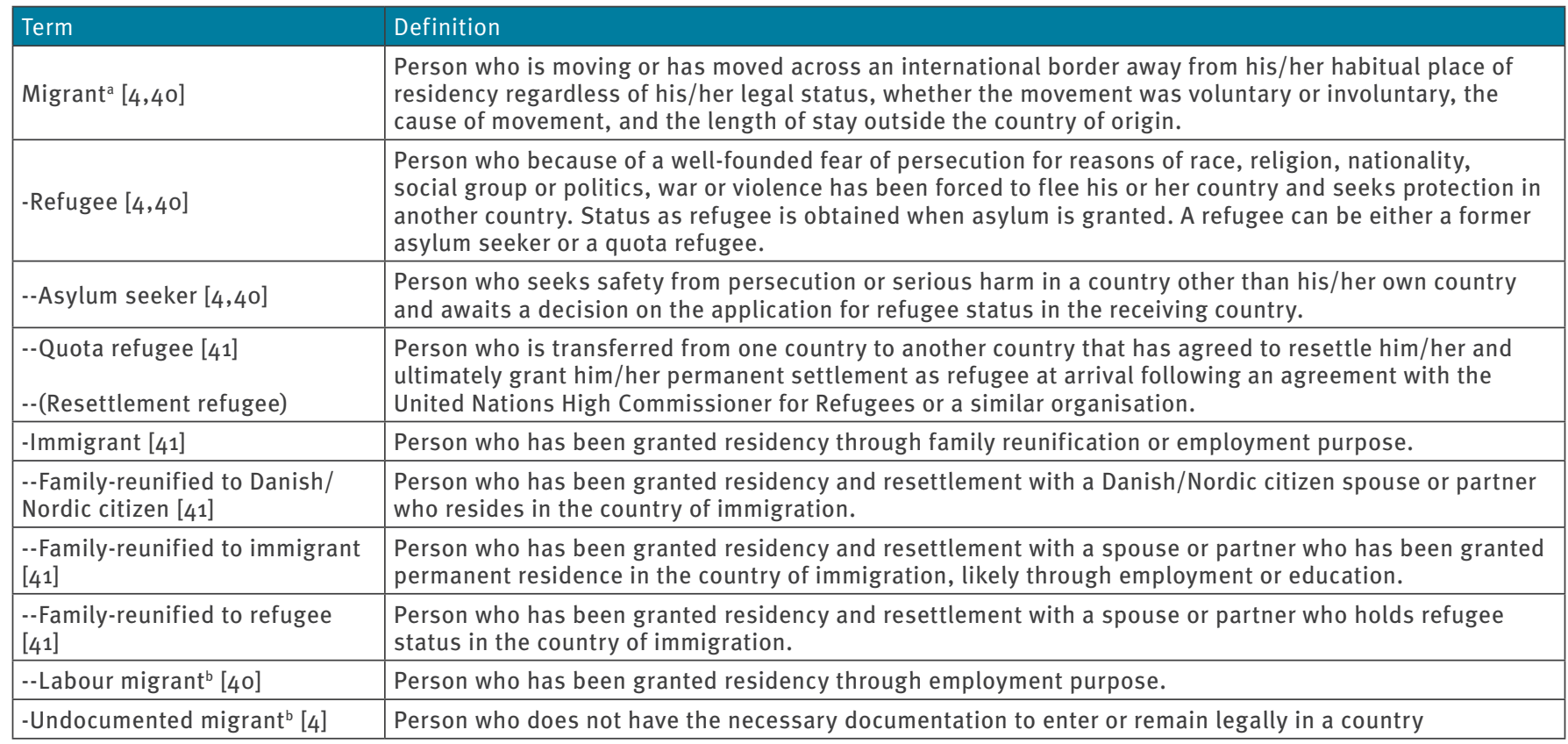

a Migrants refer to the whole group. Subgroups are defined underneath.

${ }^{b}$ Labour migrants and undocumented migrants are not included in the current study.

TB in low-incidence countries with programmes focusing on active TB screening before and at arrival [13]. In Denmark, a voluntary medical assessment is provided for asylum seekers when they arrive at the national reception centre. Since 2002 , national guidelines have recommended screening for TB among asylum seekers from high-incidence countries, but formalised, systematic screening was not effectuated before 2017 [14]. There is no systematic health or TB screening among quota refugees or family-reunified migrants [15].

A better understanding of the patterns of TB risk among migrants is needed to tailor health services according to needs and to optimise policies for migrants' contact with healthcare systems. The majority of previous studies have focused on region of origin as a risk factor, but recently there has been a focus on migrant status as such [16]. Migrant status is of interest because exposure to TB risk factors and access to TB screening differs. Only a few studies have assessed TB incidence among subgroups of migrants and how different types of migration affects the risk of TB $[9,17]$.

To investigate differences in risk of TB across migrant groups, we compared TB incidence according to migrant status and region of origin with a Danish-born population in a large-scale cohort study among migrants in Denmark spanning 23 years.

\section{Methods}

\section{Design and study population}

This register-based, prospective cohort study used data obtained from the Danish Immigration Service and from Statistics Denmark. All migrants $\geq 18$ years of age who obtained residency in Denmark between 1 January 1993 and 31 December 2015 were included. The age cut-off was used because this is the cut-off between being a child or an adult in Denmark at arrival following the United Nations (UN) Convention on the Rights of the Child [18].

Individuals were included from the date of receiving residency. Date of residency was used for this study because it is an official registered date available for all migrants in Denmark while registered dates of entry are much more uncertain and not available for all migrants. A Danish-born comparison group was identified through Statistics Denmark and matched 1:6 on age and sex based on the first day of the year when the migrant-match was granted residency. Migrants with a diagnosis of TB before the date of residency were excluded for further analysis. The construction of the cohort has previously been described in more detail including the matching procedure and exclusion process because of missing values $[19,20]$.

A TB case was defined as active TB, including both pulmonary and extrapulmonary TB. 


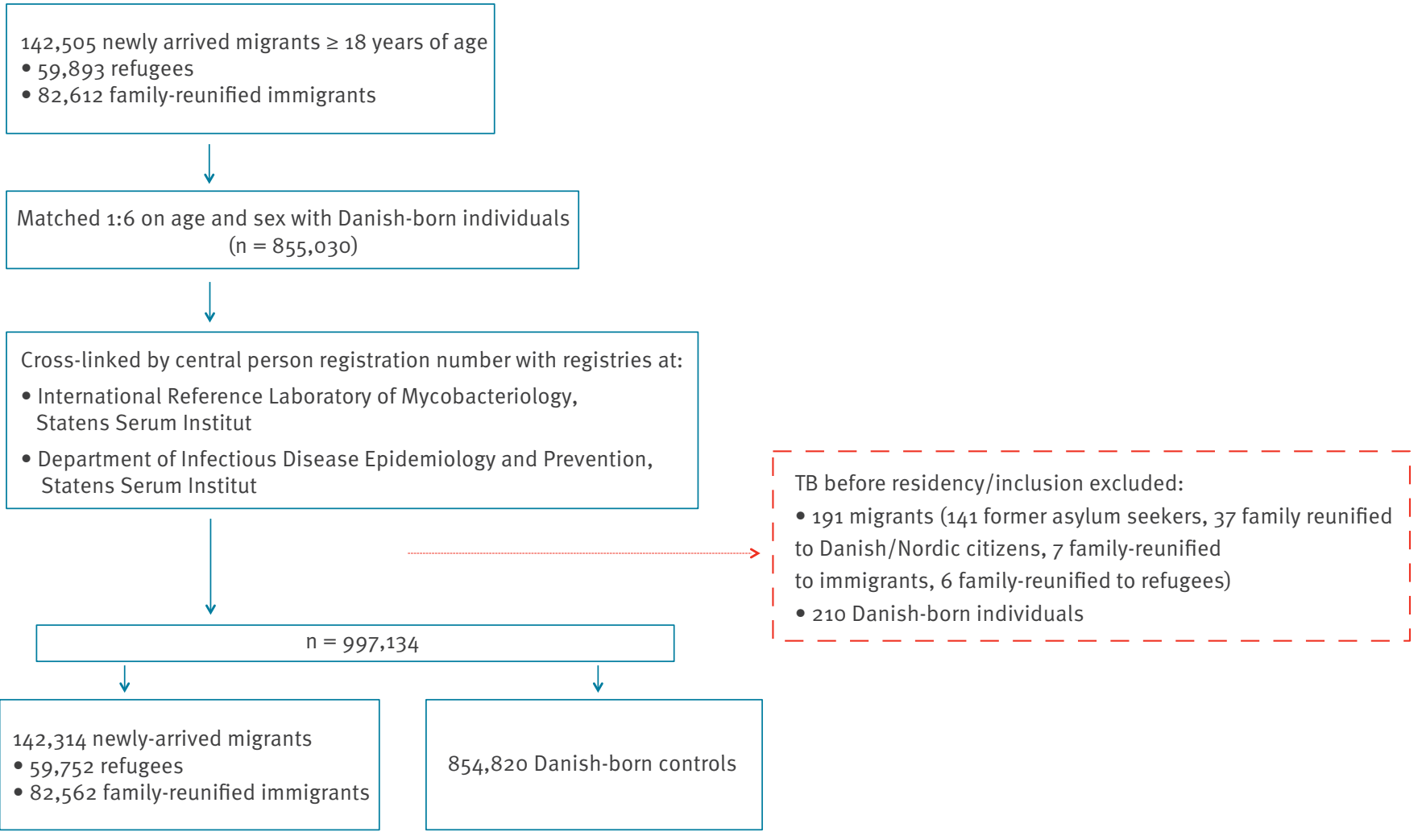

Migrants were grouped into five groups based on the legal basis of their residence: (i) former asylum seekers, (ii) quota refugees, (iii) family-reunified to Danish/ Nordic citizens, (iv) family-reunified to immigrants, and (v) family-reunified to refugees (Table 1). Migrants were grouped into six groups according to region of origin, with these regions being modified versions of those used by the World Bank Group [21]: (i) Eastern EuropeandCentral Asia; (ii) Europe, North America and Oceania; (iii) Middle Eastand North Africa; (iv) Latin America and the Caribbean; (v) South Asia, East Asia andPacific, hereafter referred to as South-East Asia; and (vi) sub-Saharan Africa (countries represented in the cohort are listed in Supplementary Table $\mathrm{S} 1)$.

\section{Data generation}

All Danish-born individuals are assigned a unique 10-digit central person registration (CPR) number at birth whereas migrants receive a CPR number at date of residency. The CPR number can be used to track individuals through public registries at an individual level. Migrant status and country of origin were obtained from the Danish Immigration Service. Data on age, sex, immigration and emigration were obtained from Statistics Denmark. Data on TB cases were obtained via cross- linkage of CPR numbers through the International Reference Laboratory of Mycobacteriology (IRLM) and the National Surveillance Register (NSR), Department of Infectious Disease Epidemiology and Prevention
(DIDE) both at Statens Serum Institut, Copenhagen. In Denmark, all TB diagnostics are centralised at IRLM and nationwide data on culture-verified TB cases were retrieved from here. TB is a notifiable disease by law and the treating physician submits a notification to the NSR, DIDE. We retrieved data on all notified TB cases from the NSR, DIDE to ensure the inclusion of culturenegative cases, i.e. patients with clinical or paraclinical findings suggestive of TB and prompting TB treatment. Since HIV is a known risk factor for TB [22], we retrieved HIV diagnoses from the NSR, DIDE in order to characterise risk-profile of the cohort.

\section{Data analysis}

Descriptive analyses were carried out using chi-squared and t-test analyses. Poisson regression analysis was used to calculate incidence rates (IR) and incidence rate ratios (IRR) of TB with $95 \%$ confidence intervals (CI) and using the logarithm of follow-up time as offset. Follow-up time was calculated as time from inclusion until: (i) TB diagnosis, (ii) emigration, (iii) death or (iv) study end whichever came first and was used to quantify the number of years a person was at risk of TB.

First, we calculated IRR for TB adjusted for age and sex, and stratified for migrant status and region of origin using Danish-born as the reference group. We identified interactions between sex and migrant status, and between sex and region of origin. We present data as overall for migrants compared with the Danish-born 
population. In order to determine the potential influence of migrant status, we calculated IRR for TB among migrants in a model adjusted for age, sex and region of origin, and stratified for migrant status and region of origin using asylum seekers as the reference group. We included age as a time-varying covariate and adjusted for age in 10-year intervals.

All analyses were performed in SAS version 9.4 (SAS Institute, Cary, United States (US)).

We reported our study results according to the STROBE guidelines [23].

\section{Ethical approval}

This study was approved by the Danish Data Protection Agency (Number 2016-41-4576). No further ethical approval is required in Denmark for registry-based research. Data were analysed anonymously via online access to Statistics Denmark's database.

\section{Results}

In total, 142,314 migrants were included in the cohort (Figure). Of these, $40.9 \%$ were family-reunified to Danish/Nordic citizens, $37.9 \%$ were former asylum seekers and $10.3 \%$ were family-reunified to refugees (Table 2). A total of 854,820 Danish-born individuals made up the control cohort. The distribution of region of origin differed. The Middle East and North Africa were the most common region of origin for familyreunified to refugees $(42.9 \%)$, former asylum seekers (37.6\%) and quota refugees (35.9\%) whereas Eastern Europe and Central Asia was the most common for family-reunified to immigrants (55.9\%) and SouthEast Asia for family-reunified to Danish/Nordic citizens $(33.1 \%)$ ( $p<0.01)$. Among migrants, $56.1 \%$ were female and the proportion of females was higher among family-reunified to refugees (80.8\%), family-reunified to Danish/Nordic citizens (68.3\%) and family-reunified to immigrants $(64.2 \%)$ in contrast to quota refugees $(40.5 \%)$ and former asylum seekers $(36.4 \%)(p<0.01)$.

We found 1,841 TB cases among migrants and 398 among the Danish-born population. Characteristics are presented in Table 3. The distribution of region of origin differed among groups with most former asylum seekers $(71.4 \%)$ and family-reunified to refugees (75.4\%) being from sub-Saharan Africa, whereas most quota refugees (51.2\%), family-reunified to Danish/ Nordic citizens $(66.1 \%)$, and family-reunified to immigrants $(44.6 \%)$ were from South-East Asia ( $p<0.01$ ) (Table 3). Among migrants, $53.3 \%$ of TB cases were female ( $p<0.01$ ), whereas $39.2 \%$ of TB cases among the Danish-born population were female $(p<0.01)$. Among migrant groups, the proportion of females was higher among family-reunified to refugees (73.2\%) and family-reunified to Danish/Nordic citizens ( $71.5 \%$ ) in contrast to among former asylum seekers ( $42.8 \%)$ and quota refugees $(25.6 \%)(p<0.01)$.
Among TB cases, the prevalence of HIV among migrants was $2.3 \%$ and among the Danish-born population 2.0\% $(p=0.72)$. The highest prevalence of HIV was seen among quota refugees $(6.4 \%)$ and family-reunified to Danish/Nordic citizens $(6.2 \%)$ ( $p<0.01)$.

Overall, the IR of TB among migrants was 120 per 100,000 person-years of follow-up (PY) (95\% Cl: 115126) compared with the Danish-born population who had an IR of 4 per 100,000 PY (95\% Cl: 3-4) (Table 4). The IR was highest among family-reunified to refugees (199/100,000 PY; 95\% Cl: 179-221), quota refugees (192/100,000 PY; $95 \% \mathrm{Cl}: 161-229)$ and former asylum seekers (156/100,000 PY; 95\% Cl: 146-167) (p<0.01). According to region of origin, the IR was highest among migrants from sub-Saharan Africa (575/100,000 PY; 95\% Cl: 541-611) with especially high IR among migrants from Somalia (849/100,000 PY; 95\% Cl: 794-907). From Somalia, former asylum seekers (883/100,000 PY; 95\% Cl: 816-955) and family-reunified to refugees (787/100,000 PY; 95\% Cl: 693-895) had the highest IR, whereas family-reunified to Danish/ Nordic citizens had the lowest IR (575/100,000 PY; 95\% Cl: 239-1,382).

Compared with the Danish-born population, the adjusted IRR of TB was significantly higher among all migrant groups ( $p<0.01)$. Especially high IRR were seen among family-reunified to refugees $(61.8 ; 95 \% \mathrm{Cl}$ : $52.7-72.4)$, quota refugees (46.0; $95 \% \mathrm{Cl}: 36.6-57.6)$ and former asylum seekers (45.3; $95 \% \mathrm{Cl}$ : 40.2-51.1). When looking at region of origin, the IRR were significantly higher among all regions of origin ( $p<0.01$ ), with especially high IRR among migrants from sub-Saharan Africa (151.2; 95\% Cl: 134.4-170.2) and South-East Asia (41.5; 95\% Cl: 36.2-47.6).

Table 5 shows IR and IRR of TB among migrants by migrant status and region of origin. Overall, familyreunified to refugees, quota refugees and former asylum seekers had the highest IR. After adjusting for age, sex and region of origin, the IRR of TB was significantly lower for family-reunified to Danish/Nordic citizens ( $0.45 ; 95 \% \mathrm{Cl}: 0.39-0.80)$ and family-reunified to immigrants $(0.64 ; 95 \% \mathrm{Cl}: 0.51-0.80)$ compared with former asylum seekers. There was no difference between quota refugees, family-reunified to refugees and former asylum seekers.

In the stratified analysis for migrant status and region of origin, the highest IR was seen for migrants from sub-Saharan Africa, particularly among former asylum seekers, family-reunified to refugees and quota refugees ( $p$ <0.01) (Table 5). Among migrants from sub-Saharan Africa, the adjusted IRR was significantly lower for quota refugees $(0.45 ; 95 \% \mathrm{Cl}: 0.34-0.61)$, family-reunified to Danish/Nordic citizens (0.22; 95\% $\mathrm{Cl}: 0.17-0.28)$ and family-reunified to immigrants (o.28; $95 \% \mathrm{Cl}$ : 0.15-0.53) compared with former asylum seekers. There was no difference between former asylum seekers and family-reunified to refugees (0.95; 95\% Cl: 0.82-1.11). 
TABLE 2

Baseline characteristics of study cohort by migrant status, Denmark, 1993-2015 (n = 997,134)

\begin{tabular}{|c|c|c|c|c|c|c|c|c|c|c|c|c|c|c|}
\hline \multirow[t]{2}{*}{ Characteristics } & \multicolumn{2}{|c|}{ Danish-born } & \multicolumn{2}{|c|}{ All migrants } & \multicolumn{2}{|c|}{$\begin{array}{c}\text { Former asylum } \\
\text { seekers }\end{array}$} & \multicolumn{2}{|c|}{$\begin{array}{l}\text { Quota } \\
\text { refugees }\end{array}$} & \multicolumn{2}{|c|}{$\begin{array}{c}\text { Family-reunified to } \\
\text { Danish/Nordic citizens }\end{array}$} & \multicolumn{2}{|c|}{$\begin{array}{l}\text { Family-reunified } \\
\text { to immigrants }\end{array}$} & \multicolumn{2}{|c|}{$\begin{array}{c}\text { Family-reunifiec } \\
\text { to refugees }\end{array}$} \\
\hline & $\%$ & $n$ & $\%$ & $n$ & $\%$ & $n$ & $\%$ & $\mathrm{n}$ & $\%$ & $n$ & $\%$ & $\mathrm{n}$ & $\%$ & $n$ \\
\hline Total cohort & 85.7 & 854,820 & 14.3 & 142,314 & 37.9 & 53,860 & 4.1 & 5,892 & 40.9 & 58,135 & 6.9 & 9,780 & 10.3 & 14,647 \\
\hline $\begin{array}{l}\text { Age at } \\
\text { residency } \\
\text { (migrants) or } \\
\text { cohort inclusion } \\
\text { (Danish-born } \\
\text { population), } \\
\text { years (mean, } \\
\text { SD) }\end{array}$ & 32.7 & 10.7 & 32.7 & 10.7 & 34.3 & 11.8 & 33.1 & 11.1 & 31.8 & 9.2 & 29.1 & 10.1 & 32.4 & 11.0 \\
\hline \multicolumn{15}{|l|}{ Sex } \\
\hline Female & 56.1 & \begin{tabular}{|l|}
479,189 \\
\end{tabular} & 56.1 & \begin{tabular}{|l|}
79,784 \\
\end{tabular} & 36.4 & 19,582 & 40.5 & 2,384 & 68.3 & 39,706 & 64.2 & 6,277 & 80.8 & 11,835 \\
\hline Male & 43.9 & 375,631 & 43.9 & 62,530 & 63.4 & 34,278 & 59.5 & 3,508 & 31.7 & 18,429 & 35.8 & 3,503 & 19.2 & 2,812 \\
\hline \multicolumn{15}{|c|}{ Region of origin } \\
\hline $\begin{array}{l}\text { Eastern Europe } \\
\text { and Central Asia }\end{array}$ & NA & NA & 24.4 & 34,755 & 33.9 & 18,263 & 0.7 & 41 & 16.8 & 9,791 & $55 \cdot 9$ & 5,471 & 8.1 & 1,189 \\
\hline $\begin{array}{l}\text { Europe, North } \\
\text { America and } \\
\text { Oceania }\end{array}$ & NA & NA & 10.8 & 15,354 & 0.4 & 234 & 0.0 & 1 & 24.2 & 14,066 & 6.1 & 599 & 3.1 & 454 \\
\hline $\begin{array}{l}\text { Latin } \\
\text { America and the } \\
\text { Caribbean }\end{array}$ & NA & NA & 3.5 & 4,955 & 0.1 & 44 & 3.0 & 177 & 7.9 & 4,612 & 0.9 & 87 & 0.2 & 35 \\
\hline $\begin{array}{l}\text { Middle } \\
\text { East and North } \\
\text { Africa }\end{array}$ & NA & NA & 25.1 & 35,733 & 37.6 & 20,263 & 35.9 & 2,119 & 10.3 & 5,970 & 11.2 & 1,099 & 42.9 & 6,282 \\
\hline South-East Asia & NA & NA & 22.4 & 31,911 & 9.8 & 5,271 & 33.8 & 1,992 & 33.1 & 19,238 & 20.4 & 1,995 & 23.3 & 3,415 \\
\hline $\begin{array}{l}\text { Sub-Saharan } \\
\text { Africa }\end{array}$ & NA & NA & 13.8 & 19,606 & 18.2 & 9,785 & 26.5 & 1,562 & 7.7 & 4,458 & 5.4 & 529 & 22.3 & 3,272 \\
\hline \multicolumn{15}{|c|}{10 most frequent countries of origin } \\
\hline Afghanistan & $\mathrm{NA}$ & NA & 4.6 & 6,487 & 7.9 & 4,240 & 6.7 & 394 & 0.4 & 215 & 0.5 & 45 & \begin{tabular}{|l|}
10.9 \\
\end{tabular} & 1,593 \\
\hline $\begin{array}{l}\text { Bosnia and } \\
\text { Herzegovina }\end{array}$ & NA & NA & 10.5 & 14,918 & 25.8 & 13,879 & 0.0 & 0.0 & 0.7 & 389 & 0.8 & 75 & 3.9 & 575 \\
\hline Iran & NA & NA & 3.7 & 5,235 & 4.2 & 2,249 & 12.3 & 723 & 2.1 & 1,239 & 0.8 & 81 & 6.4 & 943 \\
\hline Iraq & NA & NA & \begin{tabular}{|l|}
8.6 \\
\end{tabular} & 12,166 & 13.4 & 7,194 & \begin{tabular}{|l|}
19.8 \\
\end{tabular} & 1,167 & 1.0 & 552 & 0.8 & 74 & 21.7 & 3,179 \\
\hline Philippines & NA & NA & 2.6 & 3,713 & 0.0 & 2 & 0.0 & 0 & 6.1 & 3,521 & 1.8 & 172 & 0.1 & 18 \\
\hline Russia & NA & NA & 2.4 & 3,359 & 1.6 & 876 & 0.3 & 20 & 3.9 & 2,236 & 1.0 & 94 & 0.9 & 133 \\
\hline Somalia & NA & NA & 6.4 & 9,144 & 11.1 & 5,963 & 3.8 & 222 & 0.3 & 156 & 0.5 & 53 & 18.9 & 2,750 \\
\hline Syria & NA & NA & 8.4 & 11,951 & 18.6 & 9,989 & 3.1 & 181 & 0.3 & 200 & 0.3 & 33 & 10.6 & 1,548 \\
\hline Thailand & NA & NA & 5.0 & 7,133 & 0.0 & 1 & 0.0 & 0 & 12.0 & 6,967 & 1.4 & 139 & 0.3 & 26 \\
\hline Turkey & NA & NA & 6.4 & 9,087 & 0.1 & 58 & 0.0 & 2 & 8.6 & 4,981 & 40.3 & 3,945 & 0.7 & 101 \\
\hline HIV positive & 0.1 & 401 & 0.4 & 540 & 0.1 & 74 & 1.4 & 83 & 0.6 & 333 & 0.3 & 25 & 0.2 & 25 \\
\hline $\begin{array}{l}\text { Follow-up time, } \\
\text { years (mean, } \\
\text { SD) }\end{array}$ & 12.4 & 7.1 & $7 \cdot 3$ & 10.8 & 11.0 & 8.0 & 11.1 & 6.6 & 10.0 & 6.6 & 13.3 & 6.8 & 11.3 & 6.9 \\
\hline \multicolumn{15}{|l|}{ Events follow-up } \\
\hline $\begin{array}{l}\text { Tuberculosis } \\
\text { cases }\end{array}$ & 0.04 & 398 & 1.3 & 1,841 & 1.7 & 923 & 2.1 & 125 & 0.6 & 372 & 0.9 & 92 & 2.3 & 329 \\
\hline Death & 3.6 & 30,565 & 2.5 & 3,559 & 4.1 & 2,227 & 3.0 & 176 & 1.3 & 738 & 1.9 & 182 & 1.6 & 236 \\
\hline Emigration & 0.0 & 0 & 14.3 & 20,365 & 10.1 & 5,541 & 7.6 & 449 & 19.3 & 11,218 & 11.7 & 1,147 & 14.4 & 2,110 \\
\hline $\begin{array}{l}\text { Population at } \\
\text { study end }\end{array}$ & 96.4 & 823,857 & 81.9 & 116,549 & 84.1 & 45,269 & 87.3 & 5,142 & 78.8 & 45,807 & 85.5 & 8,359 & 81.7 & 11,972 \\
\hline
\end{tabular}

NA: not applicable; SD: standard deviation.

Data are presented as \% (n) unless otherwise stated. 


\section{Discussion}

Overall, all migrants in this study experienced significantly higher TB incidence compared with Danish-born across all migrant statuses and regions of origin. The study showed a difference in TB risk across migrant groups with higher risk among family-reunified to refugees, quota refugees and former asylum seekers, whereas family-reunified to Danish/Nordic citizens and family-reunified to immigrants had lower risks.

Other studies have also found a high risk of TB among migrants $[9,17,24-26]$. The TB incidence in our migrant population was 120 per 100,000 PY (95\% Cl: 115-126) over a mean study period of 10.8 years, and was 30 times higher than the incidence among the Danishborn population. This incidence was higher than that of a study among migrants in Norway (80/100,000 PY; $95 \% \mathrm{Cl}: 76-84)$ following migration [26]. One potential reason for the difference could be that the Norwegian cohort included migrants as young as 5 years of age, which could contribute to a lower TB incidence. A study among migrants in the UK found a TB incidence of 147 per $100,000 \mathrm{PY}(95 \% \mathrm{Cl}: 140-154)$ following migration [9], which was higher than the TB incidence in our cohort. In the UK study, migrants were predominantly from TB high-risk countries, whereas the migrants in our study were from both low- and high-risk countries (Supplementary Table S1).

Some studies have also included the role of migration status as TB risk factor. In a study from Canada, being a refugee or a family-reunified immigrant was a strong predictor of TB following migration compared with being a business or labour immigrant [17]. Asylum seekers and quota refugees were presented as one refugee group. The study from the UK [9] also reported that family-reunified immigrants experienced the highest TB incidence (320/100,000 PY; 95\% Cl: 244-419) among migrants, which was otherwise comprised of resettlements and dependents, students and working immigrants. This TB incidence was markedly higher than the TB incidence among our family-reunified immigrants (91/100,000 PY; 95\% Cl: 85-97), but the demographics of family-reunified immigrants in the UK were not specified in more detail so we do not know whether the two populations were comparable.

The higher proportion of females among migrant TB cases than the Danish-born population is likely to reflect an overall difference in the distribution of sex in the migrant population with more females than males resettling in Denmark. The calculated TB risk was slightly lower among female than male migrants (IRR: 0.82 ; 95\% Cl: 0.75-0.90, data not shown), which is consistent with what was found in western Sweden [27]. When looking at migrant status, the proportions differed. Male and female migrants differ in their patterns of migration which reflects in the sex distribution. Most male migrants arrive as asylum seekers or quota refugees, whereas many female migrants arrive as either family-reunified to refugees or family-reunified to Danish/Nordic citizens. Among the Danish-born population, TB cases were most often in males, consistent with the general pattern in Denmark, where TB among the Danish-born population is associated with risk factors such as male sex and social marginalisation [28].

High rates of TB according to region of origin are well known from TB surveillance data in low incidence TB countries in western Europe. Migrants from TB endemic countries, particularly from countries in sub-Saharan Africa and South-East Asia, have consistently been shown to have elevated TB rates following migration $[9,22,29]$. In our study, nearly half of migrant TB cases were from Somalia and thereby contributed largely to the risk of TB. Another important aspect was that TB cases among former asylum seekers and family-reunified to refugees were mainly from sub-Saharan Africa, especially Somalia (68.0\%), largely driving the risk of TB in these migrant groups. Somalia is a high-incidence country (IR: 266/100,000 PY [3]) and Somali migrants constitute a long-term, high-risk group in Scandinavian countries [27,30,31]. However, even though Somalia is a high-incidence country, the incidence in our cohort among asylum seekers from Somalia was much higher than the reported incidence in Somalia. In contrast, family-reunified to Danish/Nordic citizens from Somalia had lower incidence. This may possibly reflect risk factors among asylum seekers related to migration such as history of imprisonment, overcrowding and precarious living conditions, compared to family-reunified to Danish/Nordic citizens who typically travel under less strenuous means and arrive directly from their country of origin. This association with migrant status among refugees from Africa has also been observed elsewhere. Asylum seekers from western Africa arriving in Italy had a higher yield of TB screening at arrival than the incidence in their country of origin [32]. Although, one important notion is, that reported TB notifications from African countries is likely to be underreported.

Migrants accounted for a larger proportion of HIV than the Danish-born population, consistent with epidemiological HIV patterns in western Europe [33]. Quota refugees and family-reunified to Danish/Nordic citizens comprised the largest groups of HIV positive migrants and the majority came from countries with on-going HIV epidemics, such as Congo, Kenya and Thailand [34]. Most migrants are infected abroad and unaware of their HIV status, and seeking treatment is usually not the reason for migrating [33]. Interestingly, a previous study found that family-reunified to DanishNordic citizens were later presenters of HIV than quota refugees [35]. One potential reason may be that quota refugees are offered voluntary HIV testing by the International Organisation for Migration before arrival in Denmark and a potential HIV diagnosis is followed up after arrival. Family-reunified immigrants are not offered any health assessment upon arrival and the 
TABLE 3

Baseline characteristics of tuberculosis cases ${ }^{a}$ in study cohort by migrant status, Denmark, 1993-2015 (n = 2,239)

\begin{tabular}{|c|c|c|c|c|c|c|c|c|c|c|c|c|c|c|}
\hline \multirow{2}{*}{ Characteristics } & \multicolumn{2}{|c|}{ Danish-born } & \multicolumn{2}{|c|}{ All migrants } & \multicolumn{2}{|c|}{$\begin{array}{c}\begin{array}{c}\text { Former asylum } \\
\text { seekers }\end{array} \\
\end{array}$} & \multicolumn{2}{|c|}{$\begin{array}{l}\text { Quota } \\
\text { refugees }\end{array}$} & \multicolumn{2}{|c|}{$\begin{array}{c}\text { Family-reunified to } \\
\text { Danish/Nordic citizens }\end{array}$} & \multicolumn{2}{|c|}{$\begin{array}{l}\text { Family-reunified } \\
\text { to immigrants }\end{array}$} & \multicolumn{2}{|c|}{$\begin{array}{l}\text { Family-reunified } \\
\text { to refugees }\end{array}$} \\
\hline & $\%$ & $n$ & $\%$ & $\mathrm{n}$ & $\%$ & $\mathrm{n}$ & $\%$ & $\mathrm{n}$ & $\%$ & $\mathrm{n}$ & $\%$ & $\mathrm{n}$ & $\%$ & $n$ \\
\hline $\begin{array}{l}\text { Age at diagnosis, } \\
\text { years (mean, SD) }\end{array}$ & 42.1 & 10.8 & 36.0 & 12.2 & 36.9 & 13.1 & 35.9 & 12.2 & 34.6 & 9.1 & 33.9 & 11.5 & 35.8 & 12.6 \\
\hline $\begin{array}{l}\text { Time to diagnosis, } \\
\text { years (mean, SD) }\end{array}$ & 8.8 & 5.6 & $4 \cdot 3$ & 4.1 & $4 \cdot 3$ & 4.2 & $4 \cdot 3$ & 3.8 & 4.6 & 4.1 & $4 \cdot 4$ & 4.2 & 3.9 & 3.9 \\
\hline Total TB cases & 100 & 398 & 100 & 1,841 & 100 & 923 & 100 & 125 & 100 & 372 & 100 & 92 & 100 & 329 \\
\hline \multicolumn{15}{|l|}{ Sex } \\
\hline Female & 39.2 & 156 & 53.3 & 982 & 42.8 & 395 & 25.6 & 32 & 71.5 & 266 & 52.2 & 48 & 73.2 & 241 \\
\hline Male & 60.8 & 242 & 46.7 & 859 & 57.2 & 528 & 74.4 & 93 & 28.5 & 106 & 47.8 & 44 & 26.8 & 88 \\
\hline \multicolumn{15}{|l|}{ Region of origin } \\
\hline $\begin{array}{l}\text { East } \\
\text { Europe and Central } \\
\text { Asia }\end{array}$ & NA & NA & 10.7 & 197 & 14.6 & 135 & 0.0 & 0 & 7.0 & 26 & 34.8 & 32 & 1.2 & 4 \\
\hline $\begin{array}{l}\text { Europe, North } \\
\text { America and Oceania }\end{array}$ & NA & NA & 0.8 & 15 & 0.2 & 2 & 0.0 & 0 & 2.4 & 9 & 2.2 & 2 & 0.6 & 2 \\
\hline $\begin{array}{l}\text { Middle East and North } \\
\text { Africa }\end{array}$ & NA & NA & $5 \cdot 5$ & 102 & 5.5 & 51 & 10.4 & 13 & 3.5 & 13 & 7.6 & 7 & 5.5 & 18 \\
\hline $\begin{array}{l}\text { Latin America and } \\
\text { the Caribbean }\end{array}$ & NA & NA & 0.3 & 6 & 0.1 & 1 & 0.0 & 0 & 1.3 & 5 & 0.0 & 0 & 0.0 & 0 \\
\hline South-East Asia & NA & NA & 26.2 & 483 & 8.1 & 75 & 51.2 & 64 & 66.1 & 246 & 44.6 & 41 & 17.3 & 57 \\
\hline Sub-Saharan Africa & NA & NA & 56.4 & 1,038 & 71.4 & 659 & 38.4 & 48 & 19.6 & 73 & 10.9 & 10 & 75.4 & 248 \\
\hline \multicolumn{15}{|c|}{10 most frequent countries of origin } \\
\hline Afghanistan & NA & NA & $4 \cdot 7$ & 86 & 3.1 & 57 & 3.2 & 4 & 0.3 & 1 & 0.0 & 0 & 7.3 & 24 \\
\hline $\begin{array}{l}\text { Bosnia and } \\
\text { Herzegovina }\end{array}$ & NA & NA & 5.6 & 104 & \begin{tabular}{|l|}
11.2 \\
\end{tabular} & 103 & 0.0 & 0 & 0.0 & 0 & 1.1 & 1 & 0.0 & o \\
\hline Iraq & NA & NA & 3.2 & 58 & 4.1 & 38 & 4.8 & 6 & 0.5 & 2 & 0.0 & 0 & 3.6 & 12 \\
\hline Myanmar/Burma & NA & NA & 2.2 & 40 & 0.2 & 2 & 25.6 & 32 & 0.0 & 0 & 0.0 & 0 & 1.8 & 6 \\
\hline Pakistan & NA & $\mathrm{NA}$ & 3.7 & 69 & 0.1 & 1 & 0.0 & 0 & 12.9 & 48 & 18.5 & 17 & 0.9 & 3 \\
\hline Philippines & NA & NA & 3.2 & 59 & 0.0 & 0 & 0.0 & 0 & 14.5 & 54 & 5.4 & 5 & 0.0 & 0 \\
\hline Somalia & NA & NA & 47.1 & 873 & 66.9 & 617 & 9.6 & 12 & 1.3 & 5 & 5.4 & 5 & 71.1 & 234 \\
\hline Thailand & NA & NA & 4.6 & 85 & 0.0 & 0 & 0.0 & 0 & 21.2 & 79 & 6.5 & 6 & 0.0 & 0 \\
\hline Turkey & NA & NA & 2.2 & 40 & 0.2 & 2 & 0.0 & 0 & 4.3 & 16 & 22.8 & 21 & 0.3 & 1 \\
\hline Vietnam & NA & NA & 2.7 & 51 & 0.2 & 2 & 1.6 & 2 & 7.8 & 29 & $4 \cdot 3$ & 4 & 4.2 & 14 \\
\hline HIV positive & 2.0 & 8 & 2.3 & 42 & 0.4 & 4 & 6.4 & 8 & 6.2 & 23 & $4 \cdot 3$ & 4 & 0.9 & 3 \\
\hline \multicolumn{15}{|l|}{ Disease site ${ }^{b}$} \\
\hline $\begin{array}{l}\text { Pulmonary } \\
\text { tuberculosis }\end{array}$ & 87.4 & 348 & 52.4 & 965 & 51.6 & 476 & 48.8 & 61 & 56.5 & 210 & 59.8 & 55 & 49.5 & 163 \\
\hline $\begin{array}{l}\text { Extrapulmonary } \\
\text { tuberculosis }\end{array}$ & 10.3 & 41 & 46.3 & 852 & 47.8 & 442 & 42.4 & 53 & 42.2 & 157 & 40.2 & 37 & 49.5 & 163 \\
\hline
\end{tabular}

NA: not applicable; SD: standard deviation.

a All cases of tuberculosis: all active tuberculosis cases, including both pulmonary and extrapulmonary tuberculosis.

b Site unknown not listed.

Data are presented as $n$ (\%) unless otherwise stated.

late presentation may be a reflection of differences in introduction to the Danish healthcare system, inadequate screening practises or different health-seeking behaviour [35].

TB screening has been implemented in most European countries [13]. Studies show a high risk of TB among migrants upon arrival and that patterns of migration are indicators of the risk of TB $[29,36]$. One review found a pooled prevalence of TB of 283 per 100,000 screened (95\% Cl: 216-349) among migrants at arrival [29]. When stratified, the yield among refugees was 577 per 100,000 screened (95\% Cl: 206-949), among asylum seekers it was 267 per 100,000 screened (95\% $\mathrm{Cl}$ : 194-341) and among other immigrants it was 225 per 100,000 screened ( $95 \% \mathrm{Cl}: 129-322)$. The other immigrant group were pooled from studies including students, family-reunified immigrants, labour immigrants etc. and therefore did not allow any conclusion solely regarding family-reunified immigrants. Another review reported a pooled TB prevalence of 300 per 100,000 screened (95\% Cl: 224-396) among asylum seekers at arrival [36]. The differences in TB at arrival may reflect a risk of TB related to migrant status among 
TABLE 4

Incidence rate and incidence rate ratio of tuberculosis cases ${ }^{\mathrm{a}}$ among migrants by migrant status and region of origin, Denmark, 1993-2015 ( $\mathrm{n}=997,134)$

\begin{tabular}{|c|c|c|c|c|c|}
\hline Characteristics & Total (n) & TB cases $(n)$ & $\begin{array}{c}\text { IR per } 100,000 \mathrm{PY} \\
(95 \% \mathrm{Cl})\end{array}$ & Crude IRR $(95 \% \mathrm{Cl})$ & $\begin{array}{c}\text { Adjusted IRR }{ }^{\mathrm{b}}(95 \% \\
\mathrm{CI})\end{array}$ \\
\hline \multicolumn{6}{|l|}{ Migrant status } \\
\hline Danish-born population & 854,820 & 398 & $4(3-4)$ & 1 (ref) & 1 (ref) \\
\hline Migrants & 142,314 & 1,841 & $120(115-126)$ & $32.0(28.7-35.7)$ & $32.4(29.0-36.1)$ \\
\hline Former asylum seekers & 53,860 & 923 & $156(146-167)$ & $41.6(37.0-46.9)$ & $45.3(40.2-51.1)$ \\
\hline Quota refugees & 5,892 & 125 & $192(161-229)$ & $51.1(41.8-62.5)$ & $46.0(36.6-57.6)$ \\
\hline Family-reunified to Danish/Nordic citizen & 58,135 & 372 & $64(58-71)$ & $17.1(14.9-19.7)$ & $15.8(13.6-18.4)$ \\
\hline Family-reunified to immigrant & 9,780 & 92 & $71(57-87)$ & $18.8(15.0-23.6)$ & $16.9(13.5-21.3)$ \\
\hline Family-reunified to refugee & 14,647 & 329 & $199(179-221)$ & $53.0(45.8-61.4)$ & $61.8(52.7-72.4)$ \\
\hline \multicolumn{6}{|l|}{ Region of origin } \\
\hline Denmark & 854,820 & 398 & $4(3-4)$ & 1 (ref) & 1 (ref) \\
\hline Eastern Europe and Central Asia & 34,755 & 197 & $40(35-46)$ & $10.6(8.9-12.6)$ & $10.5(8.8-12.5)$ \\
\hline Europe, North America and Oceania & 15,354 & 15 & $9(6-15)$ & $2.5(1.5-4.1)$ & $2.7(1.6-4.5)$ \\
\hline Latin America and the Caribbean & 4,955 & 6 & $14(6-31)$ & $3.7(1.6-8.2)$ & $4.1(1.8-9.1)$ \\
\hline Middle East and North Africa & 35,733 & 102 & $32(26-38)$ & $8.4(6.8-10.5)$ & $8.2(6.5-10.2)$ \\
\hline South-East Asia & 31,911 & 483 & $148(135-162)$ & $39.4(34.5-45.0)$ & $41.5(36.2-47.6)$ \\
\hline Sub-Saharan Africa & 19,606 & 1,038 & $575(541-611)$ & $153.0(136.3-171.8)$ & $151.2(134.4-170.2)$ \\
\hline \multicolumn{6}{|c|}{10 most frequent countries of origin among TB cases } \\
\hline Denmark & 854,820 & 398 & $4(3-4)$ & 1 (ref) & 1 (ref) \\
\hline Afghanistan & 6,487 & 86 & $119(96-147)$ & $31.8(25.1-40.1)$ & $31.3(24.7-39.7)$ \\
\hline Bosnia and Herzegovina & 14,918 & 104 & $42(35-51)$ & $11.3(9.1-14.0)$ & $11.9(9.5-14.8)$ \\
\hline Iraq & 12,166 & 58 & $33(26-43)$ & $8.986 .8-11.7)$ & $8.9(6.7-11.9)$ \\
\hline Myanmar/Burma & 1,188 & 40 & $418(307-570)$ & $111.4(80.5-154.2)$ & $99.0(69.5-140.9)$ \\
\hline Pakistan & 2,942 & 69 & $200(158-253)$ & $53.3(41.3-68.8)$ & $47.3(36.5-61.4)$ \\
\hline Philippines & 3,713 & 59 & $193(150-249)$ & $51.5(39.2-67.7)$ & $57.1(35.7-91.3)$ \\
\hline Somalia & 9,144 & 873 & $849(794-907)$ & $226.0(200.7-254.4)$ & $222.7(197.4-251.3)$ \\
\hline Thailand & 7,133 & 85 & $125(101-154)$ & $33.2(26.3-42.0)$ & $71.3(52.6-96.6)$ \\
\hline Turkey & 9,087 & 40 & $34(25-46)$ & $9.0(6.5-12.5)$ & $7.5(5.4-10.5)$ \\
\hline Vietnam & 2,183 & 51 & $195(148-257)$ & $52.0(38.9-69.6)$ & $54.8(39.3-76.2)$ \\
\hline
\end{tabular}

$\mathrm{CI}$ : confidence interval; IR: incidence rate; IRR: incidence rate ratio; PY: person-years; ref: reference group for comparison; TB: tuberculosis.

a All cases of tuberculosis: all active tuberculosis cases, including both pulmonary and extrapulmonary tuberculosis.

${ }^{\mathrm{b}}$ Adjusted for age and sex.

Bold indicates $\mathrm{p}<0.01$.

others, and support our results of differences in TB among migrants following resettlement.

Our study underlines that family-reunified to refugees may be a high-risk group of TB compared with other family-reunified immigrants and should be prioritised in arrival screening. Asylum seekers and quota refugees leave their home under critical events and may face overcrowded camps or prisons, poor nutrition, stress and barriers to healthcare favouring both transmission and reactivation of TB [10]. Family-reunified to refugees migrate under different legal terms than asylum seekers and quota refugees, but given that many migrate under critical events and face refugee camps etc., they might still be a highly vulnerable group compared with other family-reunified migrants. This means that even though they are legally different, the migration pattern for family-reunified to refugees is similar to that of asylum seekers. In contrast, family-reunified to Danish/ Nordic citizens and family-reunified to immigrants are more likely to travel under less strenuous means and in addition, arrive within a stronger support system.

Strengthening TB screening programmes upon arrival for high-risk groups might reduce the high rates of TB following migration. If migrants are not all equally introduced to the healthcare system or systematically offered TB screening this may contribute to inequalities among migrants [15]. Among migrants, relevant TB screening is accepted and the uptake is high [37]. Ensuring TB screening is offered to migrants most at risk, i.e. family-reunified to refugees, quota refugees and asylum seekers, would increase equity in relation 
Incidence rates and incidence rate ratios of tuberculosis cases ${ }^{\mathrm{a}}$ among migrants by migrant status and region of origin ${ }^{\mathrm{b}}$, Denmark, 1993-2015 ( $\mathrm{n}=142,314)$

\begin{tabular}{|c|c|c|c|c|c|}
\hline Migrant status & Total & $\begin{array}{c}\text { Eastern Europe and } \\
\text { Central Asia }\end{array}$ & $\begin{array}{l}\text { Middle East and North } \\
\text { Africa }\end{array}$ & South-East Asia & Sub-Saharan Africa \\
\hline \multicolumn{6}{|l|}{ IR per 100,000 PY $(95 \% \mathrm{CI})$} \\
\hline Former asylum seeker & $156(146-167)$ & $46(39-54)$ & $35(26-45)$ & $120(96-151)$ & $790(732-853)$ \\
\hline Quota refugee & $192(161-229)$ & 0 & $21(24-71)$ & $325(254-415)$ & $368(278-489)$ \\
\hline \multicolumn{6}{|l|}{ Family-reunified to: } \\
\hline - Danish/Nordics citizens & $64(58-71)$ & $24(17-36)$ & $21(12-36)$ & $136(120-154)$ & $166(132-209)$ \\
\hline - immigrants & $71(57-87)$ & $40(28-56)$ & $50(24-106)$ & $179(131-243)$ & $191(103-356)$ \\
\hline - refugees & $199(179-221)$ & $27(10-73)$ & $27(17-42)$ & $137(106-178)$ & $707(624-801)$ \\
\hline \multicolumn{6}{|l|}{ Adjusted IRRc (95\% CI) } \\
\hline Former asylum seeker & 1 (ref) & 1 (ref) & 1 (ref) & 1 (ref) & 1 (ref) \\
\hline Quota refugee & $0.81(0.67-0.98)$ & 0 & $1.25(0.68-2.29)$ & $2.56(1.83-3.57)$ & $0.45(0.34-0.61)$ \\
\hline \multicolumn{6}{|l|}{ Family-reunified to: } \\
\hline - Danish/Nordics citizens & $0.45(0.39-0.51)$ & $0.42(0.28-0.64)$ & $0.57(0.31-1.05)$ & $1.20(0.91-1.55)$ & $0.22(0.17-0.28)$ \\
\hline - immigrants & $0.64(0.51-0.80)$ & $0.65(0.44-0.95)$ & $1.39(0.63-3.07)$ & $1.44(0.98-2.11)$ & $0.28(0.15-0.53)$ \\
\hline - refugees & $0.90(0.79-1.03)$ & $0.53(0.19-1.42)$ & $0.80(0.46-1.37)$ & $1.17(0.83-1.67)$ & $0.95(0.82-1.11)$ \\
\hline
\end{tabular}

$\mathrm{Cl}$ : confidence interval; IR: incidence rate; IRR: incidence rate ratio; PY: person-years; ref: reference group for comparison.

${ }^{a}$ All cases of tuberculosis: all active tuberculosis cases, including both pulmonary and extrapulmonary tuberculosis.

b The regions of Latin America and the Caribbean, and Europe, North America and Oceania were not included in the analysis because of insufficient power.

Adjusted for age, sex and region of origin.

Bold indicates $p<0.05$.

to host populations in terms of TB prevention and access to healthcare [38].

\section{Strengths and limitations}

Major strengths of this study were the cohort size and the duration of follow-up time. Also, because of the unique possibilities of the Danish CPR number, we could identify and follow a large cohort of migrants on an individual level on a nationwide basis. Further to that, TB data were retrieved from IRLM and NSR, DIDE, which are believed to cover all TB cases diagnosed in Denmark. We therefore believe our data reflect the high TB incidence among migrants after settling in a low-incidence TB country and the differences across groups.

However, there are some limitations to consider. First, we only included migrants $\geq 18$ years of age so we cannot make any inference regarding children. At arrival in Denmark, adults and children were received differently at arrival in terms of health assessment and provision of social support during the study period, so only adults were included to minimise potential bias. Second, undocumented migrants were not represented in the study cohort and these individuals may be at high TB risk and experience significant barriers to healthcare. Third, some migrants may have had TB before arrival and before receiving residency. Because valid information on date of arrival in Denmark was not available for all migrants, we included participants based on date of residency, which is when a CPR number that allows for the exact follow-up through registries is assigned.
A consequence of this approach could be an underestimation of TB incidence in our migrant population, particularly among former asylum seekers. This is because asylum seekers apply for asylum at arrival in Denmark and there is consequently a delay between arrival and receiving residency. The delay differs during the study period, but is described as between 6 and 12 months in general [39]. Regarding quota refugees and familyreunited immigrants, they hold a residence permit when they arrive in Denmark and there is therefore usually no delay between arrival in Denmark and residency. However, because of the register-based design of this study, we do not know the time span between arrival in Europe and residency in Denmark. Forth, we compare our results to studies from other countries, but the migrant population in Denmark may look different from migrant populations in other European countries because of differences in policies, traditional migration routes, etc.

\section{Conclusion}

All migrants had increased TB risk compared with the Danish-born population. The risk was particularly high for migrants from sub-Saharan Africa, family-reunified to refugees, quota refugees and former asylum seekers. Screening programmes mostly focus on asylum seekers, but other groups at high risk of TB are missed. Thus, awareness of TB in all high-risk groups should be strengthened and TB screening programmes should be optimised. This study suggests a need for a more comprehensive approach, possibly one that incorporates 
TB screening into a general health evaluation to improve migrant health.

\section{Conflict of interest}

None declared.

\section{Authors' contributions}

KLK, TLL, JHP, SH, LN, JSF, PHA, PR and MN contributed to the study design and formulating the research question. KLK and JHP performed the statistical analysis. KLK, TLL, JHP, SH, LN, JSF, PHA, PR and MN all contributed to interpreting data, drafting the manuscript and revising it critically. All authors have approved the final manuscript for publication and agreed to be accountable for all aspects of the work.

\section{References}

1. World Health Organization (WHO). Framework towards tuberculosis elimination in low-Incidence countries. Geneva: WHO; 2014. Available from: http://who.int/tb/publications/ elimination_framework/en/

2. Pareek M, Greenaway C, Noori T, Munoz J, Zenner D. The impact of migration on tuberculosis epidemiology and control in highincome countries: a review. BMC Med. 2016;14(1):48. https:// doi.org/10.1186/s12916-016-0595-5 PMID: 27004556

3. World Health Organization (WHO). Tuberculosis country profile. Geneva: WHO;2017. Available from: https://www.who.int/tb/ country/data/profiles/en/

4. Lönnroth K, Mor Z, Erkens C, Bruchfeld J, Nathavitharana $R R$, van der Werf MJ, et al. Tuberculosis in migrants in lowincidence countries: epidemiology and intervention entry points. Int J Tuberc Lung Dis. 2017;21(6):624-37. https://doi. org/10.5588/ijtld.16.0845 PMID: 28482956

5. European Centre for Disease Prevention and Control (ECDC). Tuberculosis in Europe: From passive control to active elimination. Stockholm: ECDC; 2015. Available from: https:// ecdc.europa.eu/sites/portal/files/media/en/publications/ Publications/tuberculosis-evidence-brief-low-high-incidencecountries.pdf

6. Lillebaek T, Andersen ÅB, Dirksen A, Smith E, Skovgaard LT, Kok-Jensen A. Persistent high incidence of tuberculosis in immigrants in a low-incidence country. Emerg Infect Dis. 2002;8(7):679-84. https://doi.org/10.3201/eido807.010482 PMID: 12095434

7. Vos AM, Meima A, Verver S, Looman CWN, Bos V, Borgdorff $M W$, et al. High incidence of pulmonary tuberculosis persists a decade after immigration, The Netherlands. Emerg Infect Dis. 2004;10(4):736-9. https://doi.org/10.3201/eid1004.030530 PMID: 15200873

8. McPherson ME, Kelly H, Patel MS, Leslie D. Persistent risk of tuberculosis in migrants a decade after arrival in Australia. Med J Aust. 2008;188(9):528-31. https://doi. org/10.5694/j.1326-5377.2008.tb01768.x PMID: 18459925

9. Aldridge RW, Zenner D, White PJ, Williamson EJ, Muzyamba $M C$, Dhavan $P$, et al. Tuberculosis in migrants moving from high-incidence to low-incidence countries: a populationbased cohort study of 519955 migrants screened before entry to England, Wales, and Northern Ireland. Lancet. 2016;388(10059):2510-8. https://doi.org/10.1016/S01406736(16)31008-X PMID: 27742165

10. Castelli F, Sulis G. Migration and infectious diseases. Clin Microbiol Infect. 2017;23(5):283-9. https://doi.org/10.1016/j. cmi.2017.03.012 PMID: 28336382

11. Gebrezgi MT, Jimenez A, Ibanez GE. Behind the figures: High active tuberculosis cases among Eritrean asylum seekers in Germany. Int J Hyg Environ Health. 2017;220(5):886. https:// doi.org/10.1016/j.ijheh.2017.04.004 PMID: 28479080

12. de Vries SG, Cremers AL, Heuvelings CC, Greve PF, Visser BJ, Bélard S, et al. Barriers and facilitators to the uptake of tuberculosis diagnostic and treatment services by hard-toreach populations in countries of low and medium tuberculosis incidence: a systematic review of qualitative literature. Lancet Infect Dis. 2017;17(5):e128-43. https://doi.org/10.1016/S14733099(16)30531-X PMID: 28291721

13. Dara M, Solovic I, Sotgiu G, D’Ambrosio L, Centis R, Tran R, et al. Tuberculosis care among refugees arriving in Europe: a ERS/
WHO Europe Region survey of current practices. Eur Respir J. 2016;48(3):808-17. https://doi.org/10.1183/13993003.00840 2016 PMID: 27492827

14. Kristensen KL, Nørredam M, Lillebæk T, Munk-Andersen E, Ravn P. [Tuberculosis among asylum seekers]. Ugeskr Laeger. 2018;180(19):V11170828. PMID: 29761774

15. Norredam M, Olsbjerg M, Petersen JH, Bygbjerg I, Krasnik A. Mortality from infectious diseases among refugees and immigrants compared to native Danes: a historical prospective cohort study. Trop Med Int Health. 2012;17(2):223-30. https:// doi.org/10.1111/j.1365-3156.2011.02901.x PMID: 22032340

16. Lönnroth K, Shah NS, Lange C. State-of-the-art series on tuberculosis and migration. Int J Tuberc Lung Dis. 2016;20(10):1280-1. https://doi.org/10.5588/ijtld.16.0543 PMID: 27725031

17. Ronald LA, Campbell JR, Balshaw RF, Romanowski K, Roth DZ, Marra F, et al. Demographic predictors of active tuberculosis in people migrating to British Columbia, Canada: a retrospective cohort study. CMAJ. 2018;190(8):E209-16. https://doi. org/10.1503/cmaj.170817 PMID: 29483329

18. Basu Roy R, Whittaker E, Seddon JA, Kampmann B. Tuberculosis susceptibility and protection in children. Lancet Infect Dis. 2019;19(3):e96-108. https://doi.org/10.1016/S14733099(18)30157-9 PMID: 30322790

19. Norredam M, Garcia-Lopez A, Keiding N, Krasnik A. Excess use of coercive measures in psychiatry among migrants compared with native Danes. Acta Psychiatr Scand. 2010;121(2):14351. https://doi.org/10.1111/j.1600-0447.2009.01418.x PMID: 19594483

20. Nørredam M. Migration and health: exploring the role of migrant status through register-based studies. Dan Med J. 2015;62(4):B5068. PMID: 25872539

21. The World Bank. Countries and Economies. Washington: The World Bank. [Accessed 23 Oct 2019]. Available from: https:// data.worldbank.org/country

22. World Health Organization (WHO). Global tuberculosis report 2018. Geneva: World Health Organization; 2018. Available from: https://www.who.int/tb/publications/global_report/ archive/en/

23. von Elm E, Altman DG, Egger M, Pocock SJ, Gøtzsche PC, Vandenbroucke JPSTROBE Initiative. The Strengthening the Reporting of Observational Studies in Epidemiology (STROBE) Statement: guidelines for reporting observational studies. Int J Surg. 2014;12(12):1495-9. https://doi.org/10.1016/j. ijsu.2014.07.013 PMID: 25046131

24. Erkens C, Slump E, Kamphorst M, Keizer S, van Gerven PJHJ, Bwire R, et al. Coverage and yield of entry and follow-up screening for tuberculosis among new immigrants. Eur Respir J. 2008;32(1):153-61. https://doi. org/10.1183/09031936.00137907 PMID: 18287123

25. Kaushik N, Lowbridge C, Scandurra G, Dobler CC. Post-migration follow-up programme for migrants at increased risk of developing tuberculosis: a cohort study. ERJ Open Res. 2018;4(3):00008-02018. https://doi. org/10.1183/23120541.00008-2018 PMID: 30018973

26. Farah MG, Meyer HE, Selmer R, Heldal E, Bjune G. Longterm risk of tuberculosis among immigrants in Norway. Int J Epidemiol. 2005;34(5):1005-11. https://doi.org/10.1093/ije/ dyio58 PMID: 15802379

27. Svensson E, Millet J, Lindqvist A, Olsson M, Ridell M, Rastogi NWestern Sweden Tuberculosis Epidemiology Study Group. Impact of immigration on tuberculosis epidemiology in a low-incidence country. Clin Microbiol Infect. 2011;17(6):8817. https://doi.org/10.1111/j.1469-0691.2010.03358.x PMID: 20825440

28. Jensen SG, Olsen NW, Seersholm N, Lillebaek T, Wilcke T, Pedersen MK, et al. Screening for TB by sputum culture in high-risk groups in Copenhagen, Denmark: a novel and promising approach. Thorax. 2015;70(10):979-83. https://doi. org/10.1136/thoraxjnl-2015-207162 PMID: 26156525

29. Arshad S, Bavan L, Gajari K, Paget SNJ, Baussano I. Active screening at entry for tuberculosis among new immigrants: a systematic review and metaanalysis. Eur Respir J. 2010;35(6):1336-45. https://doi. org/10.1183/09031936.00054709 PMID: 19840970

30. Farah MG, Tverdal A, Selmer R, Heldal E, Bjune G. Tuberculosis in Norway by country of birth, 1986-1999. Int J Tuberc Lung Dis. 2003;7(3):232-5. PMID: 12661836

31. Guzman Herrador BR, Rønning K, Borgen K, Mannsåker T, Dahle UR. Description of the largest cluster of tuberculosis notified in Norway 1997-2011: is the Norwegian tuberculosis control programme serving its purpose for high risk groups? BMC Public Health. 2015;15(1):367. https://doi.org/10.1186/ S12889-015-1701-x PMID: 25879411 
32. Vanino E, Tadolini M, Attard L, Po C, Francia F, Giannini A, et al. Systematic Tuberculosis Screening in Asylum Seekers in Italy. Clin Infect Dis. 2017;65(8):1407-9. https://doi.org/10.1093/cid/ cix503 PMID: 29017255

33. Hamers FF, Downs AM. The changing face of the HIV epidemic in western Europe: what are the implications for public health policies? Lancet. 2004;364(9428):83-94. https://doi. org/10.1016/S0140-6736(04)16594-X PMID: 15234861

34. World Health Organization (WHO). HIV/AIDS. Data and statistics. Geneva: WHO; 2018. [Accessed 7 Jul 2019]. Available from: https://www.who.int/hiv/data/en/

35. Deen L, Cowan S, Wejse C, Petersen JH, Norredam MESCMID Study Group for Infections in Travellers and Migrants. Refugees and family-reunified immigrants have a high incidence of HIV diagnosis and late presentation compared with Danish born: a nationwide register-based cohort study. Infection. 2018;46(5):659-67. https://doi.org/10.1007/s15010-018-1167-8 PMID: 29971691

36. Bozorgmehr K, Razum O, Saure D, Joggerst B, Szecsenyi J, Stock C. Yield of active screening for tuberculosis among asylum seekers in Germany: a systematic review and metaanalysis. Euro Surveill. 2017;22(12):30491. https://doi. org/10.2807/1560-7917.ES.2017.22.12.30491 PMID: 28367795

37. Seedat F, Hargreaves S, Nellums LB, Ouyang J, Brown M, Friedland JS. How effective are approaches to migrant screening for infectious diseases in Europe? A systematic review. Lancet Infect Dis. 2018;18(9):e259-71. https://doi. org/10.1016/S1473-3099(18)30117-8 PMID: 29778396

38. Hvass AMF, Wejse C. Systematic health screening of refugees after resettlement in recipient countries: a scoping review. Ann Hum Biol. 2017;44(5):475-83. https://doi.org/10.1080/030144 60.2017.1330897 PMID: 28562071

39. Hvidtfeldt C, Schultz-Nielsen ML. Flygtninge og asylansøgere i Danmark 1992-2016. Antal, ventetid, bosætning og lovgivning. [Refugees and asylum seekers in Demark 1992-2016. Number, waiting time, settlement and legislation]. Copenhagen: ROCKWOOL Fondens Forskningsenhed; 2017. Danish. Available from: https://www.rockwoolfonden.dk/app/uploads/2017/10/ Arbejdspapir-50-Flygtninge-og-asylans\%C3\%B8gere-iDanmark-1992-2016.pdf

40. International Organization for Migration (IOM). Key Migration Terms. Geneva: IOM. [Accessed 7 Jul 2019]. Available from: http://www.iom.int/key-migration-terms

41. The Danish Immigration Service. New to Denmark. Words and concepts. Copenhangen: The Danish Immigration Service; 2018. [Accessed 23 Oct 2019]. Available from: https://www. nyidanmark.dk/en-GB/Words $\% 20$ and $\% 20$ Concepts $\% 20$ Front\%2oPage

\section{License, supplementary material and copyright}

This is an open-access article distributed under the terms of the Creative Commons Attribution (CC BY 4.0) Licence. You may share and adapt the material, but must give appropriate credit to the source, provide a link to the licence and indicate if changes were made.

Any supplementary material referenced in the article can be found in the online version.

This article is copyright of the authors or their affiliated institutions, 2019. 